\title{
THE HUMAN FACTOR AND EFFICIENT UTHIZATION OF THE LANGUAGE LABORATORY
}

\author{
by Daniel V. Deti
}

\section{Introduction}

This paper is an attempt to condense a hundred page study I conducted last year on the community college level in the state of California. The purpose of the investigation was to examine the human factors which contribute to the effectiveness of the language laboratory as an instructional aid in the field of foreign language study, and to determine the extent to which a direct relationship between effective use of the language laboratory and the human factors represented by instructors and individuals involved could be equated in terms of a predetermined act of variables cosvirite

Regardless of whether one subscribes to the Chomsky or Skinner GeH.MOD:= language learning theories, the basic aim and inherent advantage of the language laboratory is to provide the student with a maximum of controlled environment for his practice in speaking, and in listening to a language other than the native tongue. The language lab can be an "acoustic immersion tank" - a repository of cultural ambiance.

How effective is this learning process-facility? The language laboratory can be no more effective, efficient, or productive than the capability, aptitude, diligence and convictions of the personnel who operate and maintain it, the teachers who subscribe to it (or abuse it) or the students who have the opportunity to profit from its use.

Given the above conditions it is not illogical to present the following premise: given electro-mechanical operational adequacy, the human factor is the strongest variable in determining the effective use of the language laboratory as a teaching aid. The concept that the language laboratory should carry the language teaching burden is completely out of proportion to its original design and intent. It was designed to supplement the teaching process, not to supplant it.

A study of the literature published during the last ten years in the professional language journals and in state education department reports reveals a number of studies which make an issue of the "language laboratory supported audio-lingual approach" as opposed to the "reading-translation-grammar attack," in foreign language teaching methodology. These investigations and "experiments," engineered to evaluate the effectiveness of "language laboratory instructed" students, simply beg the question. 


\section{Lab Utilization}

In 1964, Dr. Joseph C. Hutchinson (at the time with the Defense Language Institute, Washington, D. C.) observed, "The language laboratory is most useful in the hands of a craftsman who knows how to use it skillfuly ... the student needs to intensify and individualize his practice of the spoken language as it has been modeled for him by a variety of native speakers ..."1 The value of the language laboratory is self-evident, but, according to Dr. Hutchinson, it is the consensus of some researchers that regardless of the contributions made by electro-mechanical teaching, this does not constitute a single variable which can be isolated ... "especially since the program itself is so much more important than the vehicle by which it is presented. The contribution the instructor makes in reinforcing the students' self-correction and practice is indispensable."

Perhaps the most critical evaluation of the human factors which result in deterioration in the proper use of the language laboratory was revealed in an investigation reported by Elton Hocking, Purdue University. After a three-year study of a single school district, his investigating committee concluded that the language laboratory, valuable device as it might be, had in fact been barely satisfactory; the average teacher was not able to cope simultaneously with the new methods, the new mechanical devices, and the new materials with which he had been confronted "all at once." 2 This study concluded by affirming that the concept of the language laboratory is a sound one, and that the excessive costs in the operation of the laboratories have been caused not by normal usage, but by teacher neglect, carelessness, and misuse, among other reasons. Dr. Hocking ends his case study with this remark, "If I were to repeat, now, the evaluation after three years, it would doubtless yield the same results: the good teachers would still be improving and the others would not."

\section{Definitions of Terms and Limitations of the Study}

For the purpose of the study, "Human Factors" were defined as those psychological behavior patterns composed of intrinsic and extrinsic opinions, attitudes, interests and values which influence the

1Joseph C. Hutchinson. "The Language Laboratory . . . How Effective Is It?" School Life, (January-February 1964).

2Elton Hocking. "A Case Study: The Language Laboratory in a Large Suburban School District." The Modern Language Journal, 52, (February 1968). 
professional adequacy of the foreign language instructor in the effective utilization of electro-mechanical language teaching media. And, of course, the language laboratory belongs to the media.

The intrinsic variables categorized in the study involved the (1) biographical data, (2) educational preparation and experience, (3) philosophy of teaching methodology, (4) value judgments and convictions of individual instructors, balanced against the extrinsic variables: (1) administrative support, (2) in-service training, (3) equipment maintenance, (4) faculty staff interest and (5) language laboratory program.

The study was not an attempt to evaluate the success to failure ratio per se of the language laboratory as a learning/teaching device in competition with other learning/teaching methodologies or media. Nor was it the purpose of the study to examine the relative merits of the so-called "software" variety of materials prepared for language laboratory programs of study. The area of the study was restricted to an analysis of the human behavioral factors which predict the effectiveness of the language laboratory utilization as they are directly equated in terms of the intrinsic and extrinsic variables previously mentioned.

\section{Procedures}

During the month of January 1971 a questionnaire entitled "Language Laboratory Utility-Analysis Survey" was mailed to 467 foreign language instructors of 90 Community Colleges of the State of California. Of the instructors polled in the survey, 160 returned the questionnaires completed, representing a 29 percent return. However, these 160 individuals were representative of 73 foreign language departments of the 90 Community Colleges queried, representing an 80 percent geographical institutional distribution over the State of California. Several of the questionnaires returned were joint departmental projects. Instructors of the California Community College system were requested to respond and comment in detail on three broad areas, (1) professional background and educational training, (2) value judgments and convictions, (3) operational circumstances and attitudes. Of the one hundred and sixty questionnaires, ten were eliminated because they were considered inappropriate, thereby reducing the operational number of questionnaires to one hundred and fifty. The respondents were divided into two groups on the basis of individual reactions to Section 2 Part II of the questionnaire. ${ }^{3}$

3The questionnaire referred to in this and subsequent sections of the text may be obtained by writing the Editor, NALLD Jourmal. 


\section{Lab Utilization}

In the opinion of the writer this particular section established the tone of the study as well as serving as a reliable point of departure from which fairly accurate assumptions could be defined and predicted in correlation with data presented in other sections of the questionnaire in developing supporting date for the hypothesis of the investigation.

For this reason the foreign language instructors of the Community College system of the State of California were encouraged to commit themselves to a sincere value judgment in response to: "Regardless of the philosophy implemented in your teaching of foreign languages, do you find the language laboratory a valuable assist in achieving your objectives? Do you find that it has any value at all in your teach. ing? If so, why? If not, why not? Will you please be so kind as to share your comments with us?"

Those who gave unequivocally and emphatically affirmative answers and who, in many cases, proceeded to enthusiastically elaborate at length on the theme, were for the purposes of this study placed in the Positive Group. Those instructors who answered with various degrees of negation from outright rejection to expressions of qualified reservations and of doubt were placed in the Negative Group.

One hundred instructors, or 67 percent, qualified for the Positive Group which endorsed the language laboratory as a valuable assist in achieving their language teaching objectives. Fifty instructors, 33 percent of the total, who rejected or expressed various degrees of skeptical reservations as to the value of the language laboratory as a language teaching aid, were classified in the Negative Group.

As recorded in the questionnaires, 65 percent of the Positive Group and 58 percent of the Negative Group had had previous teaching experience in high schools. Of these respective percentages approximately 31 percent of the high school Positive Group and approximately 30 percent of the high school Negative Group had received grants under the National Defense Education Act to participate in special training at NDEA sponsored language institutes. There was no appreciable difference in their reactions and those of Community College instructors who had begun their teaching careers directly in the Junior College system. Under the National Defense Education Act, junior college instructors have never been eligible to attend these Foreign Language Institutes.

Representative abstracts of remarks recorded by both the Postive Group and the Negative Group in response to this particular key section of the survey were quoted at length. It was the intent of the study to focus on the importance of these statements, for the documentary value of such direct case studies does reflect peer pedagog- 
ical and authoritative convictions in support of the basic premise of the investigation. In the personal estimation of the writer, both groups did themselves much credit in analyzing current instructional problems and their remarks are worthy of a pamphlet publication. However, space here permits only a few short quotes.

\section{Positive Group}

I very much favor the use of the language laboratory. I feel that it has enhanced my teaching and my students' achievement has definitely improved in speaking and understanding. It's strange, but after all these years there are still many teachers who are intimidated by laboratory equipment and who will not use the devices available. They don't belong to professional organizations either ...

The language lab is invaluable as a teaching tool ... the teacher would waste his time and lose his mind doing what the machines can do. Of course, his first task when he meets the student for the first time is to instill in him an enthusiasm for the lab so that they believe in it...

\section{Negative Group}

I believe that the language lab can be a valuable supplement to the classroom instructor, but not necessarily for all students. Some students are "turned off" by anything mechanical, and I feel that to force these students to attend lab is self defeating.

Most students are rather turned off than on by the lab. Also, I have found nothing that the lab can do that I couldn't do better in class. At any rate, I believe the enormous expense of language labs is totally out of proportion with their very limited usefulness, if any.

\section{Language Instructors' Reaction}

Administrative Support: In evaluating the degree to which they considered their administration supported the language laboratory programs in their respective colleges, (1) 50 percent of the Negative Group rated it cooperative and enthusiastic, the other 50 percent classified it in the apathetic and budget-deterrent category; (2) 70 percent of the Positive Group rated it enthusiastic and cooperative, 30 percent considered it pathetic, moderately interested, or were noncommittal in their ratings. 


\section{Lab Utilization}

Inservice Training: In response to the question involving the provision of inservice foreign language laboratory training programs by the respective colleges or foreign language departments, (1) 10 percent of the Negative Group reported such instructive programs, 60 percent their non-existence, while 30 percent were concerned enough to volunteer individual compensations, but detailed staff circumstances which frustrated the development of such programs; (2) 37 percent of the Positive Group reported inservice instructional programs, 36 percent their non-existence, and 23 percent modified their negative remarks, for the most part stipulating that reliance upon trained lab assistants, technicians, and instructors with previous experience were considered adequate substitutes.

Equipment Maintenance. In response to the query concerning maintenance of language laboratory equipment, (1) 20 percent of the Negative Group registered satisfaction with the upkeep of the equipment, 80 percent reported serious operational shortcomings; (2) 58 percent of the Positive Group reported satisfaction with the upkeep of the language laboratory equipment, 22 percent said the maintenance was quite inadequate, and 20 percent reported the maintenance sporadic or chose not to answer the question.

Faculty Interest in Language Laboratory Programs. In response to the query concerning evidence of strong language faculty interest in their respective language laboratory programs, (1) 20 percent of the Negative Group reacted in the affirmative; the remaining $\mathbf{8 0}$ percent chose to evaluate their fellow faculty members in the negative; (2) 57 percent of the Positive Group reacted to this question in the affirmative, 26 percent replied in the negative, 17 percent were moderate in their opinions or did not choose to answer the question.

Worthwhile Language Laboratory Program. In response to the question requesting a candid opinion of the "worthiness" of their respective college language laboratory programs, (1) 8 percent of the Negative Group answered "yes," 30 percent "No," and 62 percent proceeded to detail negative evaluations (" ... it will become a bigger bureaucracy wagging the puppy . . . eliminate it!"); (2) 66 percent of the Positive Group offered testimonials as to its effectiveness, 27 percent were critical of their programs (" . . only fair, because instructors do not know and apparently are unable to find out precisely what a language laboratory can or should do ...") and 7 percent chose not to answer the question. 
The Electro-Mechanics of Language Instruction. Question, "Do you feel that the electro-mechanics of language instruction are obstructive and ineffective in the long run?" (1) Approximately 39 percent of the Negative Group considered the electro-mechanics of language instruction obstructive and ineffective with the theoretical reactions of students dominating their evaluations, 40 percent felt they were not obstructive and ineffective, reinforcing their reactions with comments which favored instructional and linguistic pedagogic points of view; (2) 86 percent of the Positive Group did not consider the electro-mechanics or language instruction obstructive and ineffective, supporting their reactions with plausible justifications, 14 percent did consider the electro-mechanics of language instruction obstructive and ineffective with little additional comment.

\section{Implications of Technological Aptitude}

The inclusion of question number fifteen, Part III, "Just what aspect of man's flight to the moon do you find most intriguing?" seemed to be the product of frivolous, non-scientific whimsy. It did, nevertheless, have a rather oblique purpose, and a good 85 percent of the total number polled did answer the question with considerable sincerity and interest.

Granted, the results of such a vague question cannot be construed to be a valid indication of technological aptitude. The results revealed a marginal interest in technological detail and suggested an aptitude capability for curiosity and appreciation of electro-mechanical manipulatory systems and communications.

The sum of the reactions continued to be consistent with the percentage rations established between the Negative Group and the Positive Group. Of the 83 percent of the Positive Group who answered the question, 30 percent were impressed with the technology of man's endeavor to land on the moon. Of the 68 percent of the Negative Group who answered the question, 16 percent commented favorably on the technological knowledge and communications system required by the moon flight.

On the rather unscientific presumption that interest expressed in the technological and communication electro-mechanics of man's flights to the moon is evidence of technological aptitude, one might hazard the following suppositions: (1) 30 percent of the Positive Group which responded were so inclined; while (2) 16 percent of the Negative Group who answered demonstrated such preferences. 


\section{Lab Utilization}

\section{Summary}

The major purpose of this study has been to examine the contrasting relationships as demonstrated by direct field research between two basic criteria, a Negative Group and a Positive Group of language instructors, in correlation with human factors as defined in the text of this investigation.

A further purpose of this study has been to analyze the extent to which the results of these correlations can predictably exercise a facilitating or deterring influence on the effective use of the language laboratory as a language teaching aid. (See Tables 1 through 5.)

I. Biographical Background: Professional preparation; educational practice.

This section of the summary will evaluate the biographical and professional profiles of the 150 California Community College foreign language instructors who participated in the survey. With three possible exceptions, the information recorded in this area of the "Language Laboratory Utility-Analysis Survey" yielded no critical data which could be significantly correlated more with one group, negative or positive, than with the other. Therefore, there was no necessity to establish additional hypotheses in support of the premise of this study.

1. In both the Negative Group and the Positive Group there was a relatively equal distribution of both male and female instructors.

2. The dominant academic attainment was the Masters Degree, relatively evenly distributed in both the Negative and Positive groups among male and female instructors.

3. The Community College instructors with previous high school teaching experience, including those who had attended NDEA Institutes and those Community College instructors with no previous high school teaching experience nor NDEA training, were proportionately represented in both the Negative and Positive groups.

4. All foreign languages and language levels traditionally taught in the Community Colleges were proportionately represented in both the Negative and Positive groups.

5. It would be difficult to ascertain which particular foreign language methodology, audio-lingual or grammar-translation, dominated the teaching pedagogy of any particular instructor without actual classroom observation. Respondents of both the Negative and the Positive Group professed to practice a combination of both.

6. Statistically speaking, there was a greater percentage of native speakers and/or instructors born abroad among the Positive Group than was represented in the Negative Group.

7. Language laboratory attendance: Though marginal, the following facts may still have some significance: (a) A higher percent- 
age of the foreign language departments represented by the Positive Group made language laboratory attendance mandatory; (b) More hours per week laboratory attendance by levels were required by the Positive Group than by the Negative.

8. Professional organizations: With little exception, a greater percentage of the Positive Group were represented in the various professional organizations than were members of the Negative Group. II. Negative vs. Positive

A detailed analysis of the basic, intrinsic human factors documented by the Positive Group in response to Section 2, Part II of the questionnaire as opposed to the intrinsic human factors recorded by the Negative Group suggested enough material for an additional, indepth study. The Positive Group here exhibited human qualities of professional dedication, conviction and temperament which testified to the effective utilization of the language laboratory as a teaching aid. Members of the Negative Group demonstrated qualities of character and attitude which denied the value of the language laboratory as a teaching aid, or described deterrent, extraneous factors which limited or frustrated adequate utlization of the language laboratory.

A significant relationship was found to exist between these intrinsic negative and positive factors when compared with the extrinsic human factors revealed by the following variables:

1. Administrative support

2. Inservice training

3. Equipment maintenance

4. Faculty interest

5. Worthwhile language laboratory program

6. Did not consider electro-mech. obstructive and ineffective
Negative Group

$50 \%$
$10 \%$
$20 \%$
$20 \%$
$8 \%$

$49 \%$
Positive Group $70 \%$ $59 \%$ $58 \%$ $57 \%$

$66 \%$

As a result of these comparisons, it can be assumed that there is adequate data to support the hypothesis that there does exist a viable direct relationship between the human factors delineated in this study and the effective utilization of the language laboratory as a teaching aid.

Just to what degree such extrinsic human factors itemized above influenced the respective attitudes, opinions and value judg. ments of the Negative and Positive groups is not entirely a matter of conjecture, but the result of corroborating data supported by statistical analogies. There was sufficient evidence submitted in the course of the study to support observation that those members of the 


\section{Lab Utilization}

Negative Group whose attitudes were positive toward the utilization of the language laboratory labored under circumstances which prejudiced their concepts of its value as a teaching aid.

\section{Conclusions and Recommendations}

This study has been an attempt to isolate the intrinsic and extrinsic human factors which can constructively predict the effective utilization of the language laboratory to its full potential.

Although the administrative, operational, departmental, and personnel environmental factors were much more advantageously correlated to the Positive Group, the tabulated percentages were far from being 100 percent. A good percentage of both groups reported equivalent professional frustrations. However, the fact that 86 percent of the Positive Group did not consider the electro-mechanics of language obstructive and ineffective, focuses maximum responsibility on the instructor's attitude as a key human factor in the effective utilization of the language laboratory as a language teaching aid.

The summary and conclusions of this study, and the findings from which these conclusions evolved, suggest the following recommendations.

1. Regardless of his own personal inclinations, no administrator should employ a foreign language instructor who does not have a positive concept and theoretical knowledge (which does not necessarily suggest technological aptitude) of the maximum possibilities as well as of the limitations of electro-mechanical media in foreign language instruction.

The recurring concern recorded by the Negative Group in this study for the negative attitude on the part of students can be considered auto-suggestive, and indicative of a lack of imagination, and initiative on the part of the instructor. The inability to incorporate the utilization of language laboratory teaching aids as an integral program of a language course of study is symptomatic of instructional inadequacy.

2. The raison d'etre of any institution which presumes to prepare foreign language teachers should include a sound program of educational technology. If the resources for training the student in manipulatory techniques are limited, at least a thorough briefing in the philosophical and pedagogical implications for educational technology should be a formal addition to the curriculum.

3. The installation and maintenance of language laboratories should be required to meet state legislated specifications and regulations - (what about accountability these days?). The language instructor should be relieved of all mental hazards produced by in. 
effective equipment and electro-mechanical frustrations, as well as unrewarding problems of supervision. Though the foreign language instructor should be sensitive to the full possibilities of language teaching technology and be capable of taking full advantage of it, he should not be burdened by it.

It is hoped that this study has contributed to a better comprehension of the human factors and circumstances which influence the effective utilization of language teaching technology in the concerted efforts to continually enrich the qualities of good, constructive langauge teaching. In isolating these factors and their implications, it is sincerely desired that these findings will be instrumental in suggesting solutions as well as stimulating further remedial research in this area.

A no more appropriate ending to this study can be recommended than the following quote from a respondent critical of the research instrument used in this investigation. "This is a poorly constructed questionnaire ... these questions have been around for a long time." them.

Agreed. And so have the problems, and the people who create

\section{BIBLIOGRAPHY}

BROOKS, NELSON. "Ideal Preparation of Foreign Language Teachers." Modern Language Journal, 1966, 50, 77-8.

BROOKS, NELSON. Language and Language Learning. New York: Harcourt, Brace \& World, Inc., 1960.

CARROLL, JOHN B. The Study of Language. Cambridge: Harvard University Press, 1953.

CIOFFARI, VINCENZO. "What Can We Expect from the Language Laboratory!" Modern Language Journal, 1961, 45, 3-9.

COLEMAN, ALGERNON. The Teaching of Foreign Languages in the United States. New York: Macmillan Co., 1929.

Congress and Nation, 1945-1964. A Review of Government and Politics in the Postwar Years. Washington, D. C.: Congressional Quarterly Service.

DALBOR, JOHN B. "A Realistic Look at the Training of College Foreign Language Teachers." Modern Language Journal, 1967, 51, 211.

DUMONT, JACQUES. "More About Abuse." NALLD Journal, 1970, V, No. 11, p. 47.

HAYES, ALFRED D. "New Media for Instruction! Language Laboratory." U. S. Department of Health, Education, and Welfare, Office of Education, Bulletin 1963, No. 37. Washington, D. C.: U. S. Government Printing Office, 1963, 118 pp. 


\section{Lab Utilization}

HOLTON, J. S.; KING, P. E.; MATHIEU, G.; and POND, K. S. Sound Language Teaching. New York: University Publishers, 1961.

HUTCHINSON, JOSEPH C. "The Language Laboratory: How Effective is It?" School Life, January-February, 1964.

HUTCHINSON, JOSEPH C. "Modern Foreign Languages in High School: The Language Laboratory." U. S. Department of Health, Education and Welfare, Office of Education, Bulletin 1961, No. 23. Washington, D. C., U. S. Government Printing Office, 1961. 85 pp. JOHNSTON, MARJORIE D.; and SEERLEY, CATHARINE C. "Foreign Language Laboratories in Schools and Colleges." U. S. Department of Health, Education, and Welfare, Office of Education, Bulletin 1959, No. 3. Washington, D. C., U. S. Government Printing Office, 1959, $86 \mathrm{pp}$.

MARTY, FERNAND I. Language Laboratory Learning. Wellesley, Massachusetts: Audio-Visual Publications, 1960.

MARTY, FERNAND I. Methods and Equipment for the Language Laboratory. Middlebury, Vermont: Audio-Visual Publications, 1956.

MATHIEU, GUSTAVE. "Language Laboratories." Review of Educational Research, 1962, 32, 168-78.

MORTON, F. RAND. The Language Laboratory as a Teaching Machine. Ann Arbor, Michigan: Publications of the Language Laboratory. The University of Michigan, 1961.

PARKER, WILLIAM RILEY. "The National Interest and Foreign Languages: A Discussion Guide." Prepared for the U. S. National Commission for UNESCO, Department of State Publication 7324, Third Edition. Washington, D. C., U. S. Government Printing Office, $1962,159 \mathrm{pp}$.

STACK, EDWARD M. The Language Laboratory and Modern Language Teaching. New York: Oxford University Press, 1960.

ABOUT THE AUTHOR:

Daniel V. Deti is Chairman of the Foreign Language Department, College of the Desert, Palm Desert, California. 


\section{Blographical and Professional Profile}

Negative Group

\begin{tabular}{|c|c|c|c|c|c|c|c|c|}
\hline & & Malo I & muctors & & & male I & ructor & \\
\hline \multirow{5}{*}{ 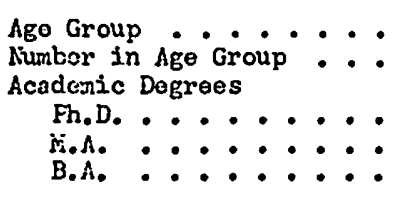 } & $20-30$ & $31-40$ & $42-55$ & $56-65$ & $20-30$ & $31-40$ & $41-55$ & $56-65$ \\
\hline & 1 & II & 12 & 5 & 6 & 4 & 9 & 2 \\
\hline & & & 2 & 4 & & & & \\
\hline & 1 & 11 & 9 & & 6 & 4 & 9 & 2 \\
\hline & & & 1 & $I$ & & & & \\
\hline \multirow{3}{*}{$\begin{array}{l}\text { Forner H.S. whth NDEA } \\
\text { Foinor hi.s. }- \text { no NDEA } \\
\text { No Provious H.S. Experienco }\end{array}$} & & 2 & 2 & & 1 & 1 & 1 & 2 \\
\hline & 1 & 4 & 6 & 3 & 3 & 1 & $\overline{2}$ & \\
\hline & & 5 & 4 & 2 & 2 & 2 & 6 & \\
\hline \multirow{3}{*}{$\begin{array}{l}\text { Native Speaker } . \cdots \\
\text { Non-liative Speaker : } \\
\text { Boun Abroad } \ldots\end{array}$} & & 1 & 5 & 1 & 1 & 2 & 4 & 1 \\
\hline & $I$ & 10 & 7 & 4 & 5 & 2 & 5 & $I$ \\
\hline & & & 5 & 1 & 1 & 2 & 2 & $I$ \\
\hline \multicolumn{9}{|l|}{$\begin{array}{l}\text { Language Lovels Taught } \\
\text { French I. II }\end{array}$} \\
\hline \multirow{2}{*}{ 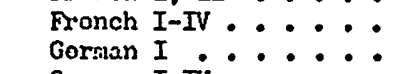 } & & 2 & 2 & 1 & 2 & 3 & 2 & 2 \\
\hline & & & & & $I$ & & & \\
\hline \multirow{3}{*}{$\begin{array}{l}\text { Gorman I-IV }: \cdots \\
\text { Italian I, II : : } \\
\text { Japaneso \& Chinose : }\end{array}$} & & 5 & 3 & 2 & $\bar{I}$ & 1 & 3 & \\
\hline & & & 1 & & & & 1 & \\
\hline & & & & & & & & \\
\hline \multirow{3}{*}{$\begin{array}{l}\text { Russian I, II } \cdots \cdots \\
\text { Russian I-IV } \because \cdots \\
\text { Spanish I II }\end{array}$} & & & & & & & & \\
\hline & & & & & & & 1 & \\
\hline & & 2 & 1 & & & & & \\
\hline \multirow{3}{*}{$\begin{array}{l}\text { Spanish I-IV } \cdots \\
\text { Spanish I-VIII : } \\
\text { Portuguose I, II }: \text { : }\end{array}$} & 1 & 2 & 4 & 2 & 1 & & 2 & \\
\hline & & 1 & 2 & & & & 1 & \\
\hline & & & & & & & & \\
\hline
\end{tabular}


TABLE 2

Biographical and Professional Profile

\section{Positive Group}

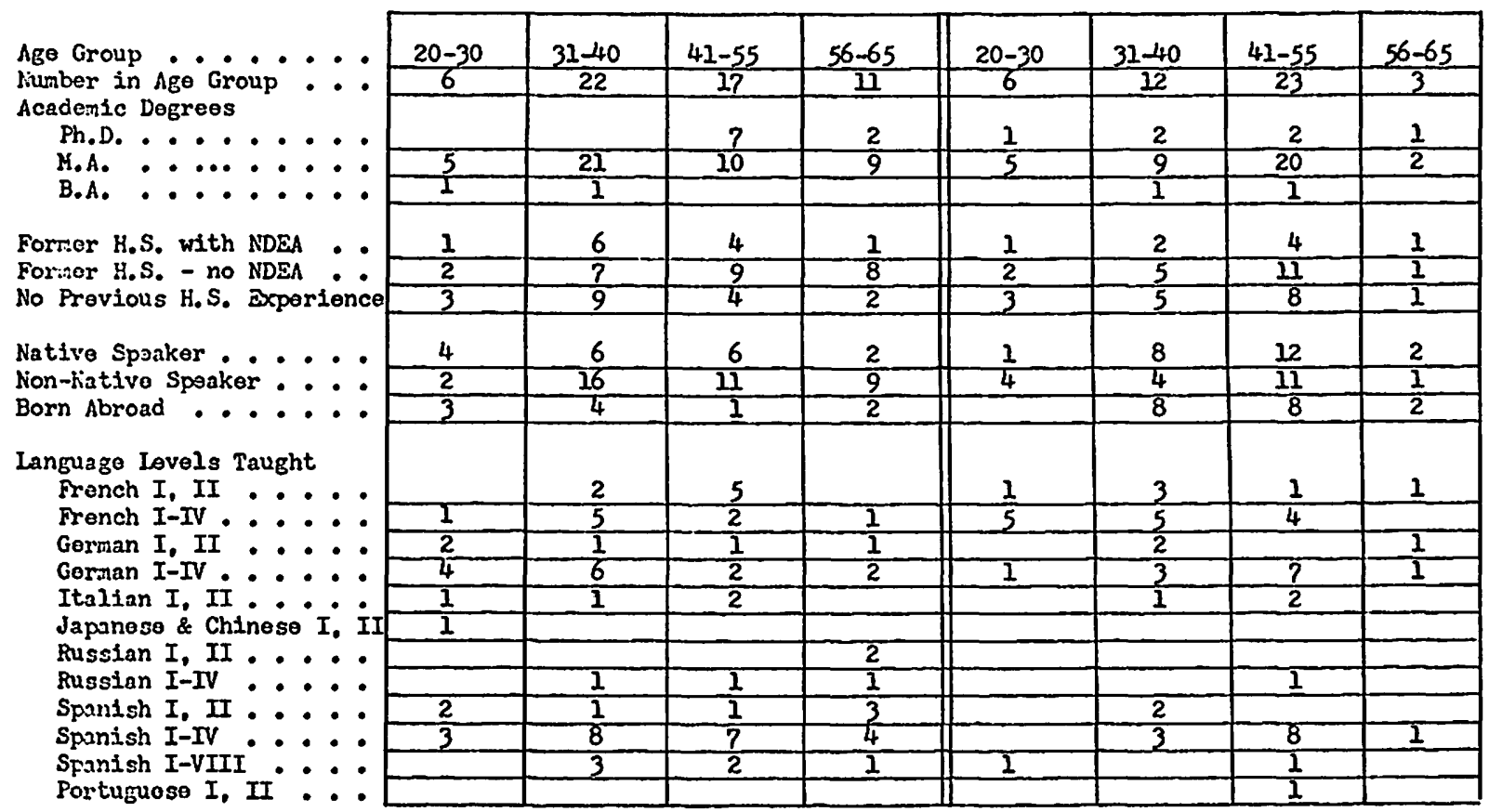




\section{TABLE 3}

\section{A. Language Laboratory Attendance}

I. Mandatory Requirement Established by Departmentel Policy: Negative Group (50 merabers) .......558 Positive Group (100 members) ...... 737

II. Individual Teachers" Option:

Negative Group (50 members) ....... 44\% Positive Group (100 members) ...... 27\%

\section{B. Language Laboratory Utilization}

I. Open Iibrary System; Individual Initiative

Negative Group (50 members) ...... 50\% Positive Group (100 members) ...... 54\%

II. Group Assignment by Class:

Negative Group (50 members) ...... $30 \%$

Positive Group (100 members) ..... 26\%

IIr. Both Open Library and Class Assigment

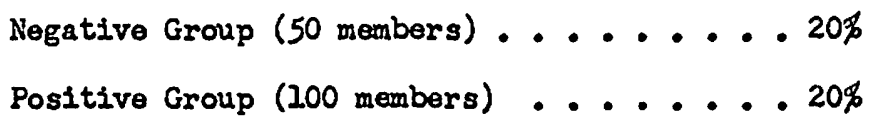


Required Language Laboratory Attendance by Lovels

A. Negative Group

First Year Lovel

$\begin{array}{ll}\text { Hours per } & \text { Percentage of Group } \\ \text { Week } & \text { Requiring Attondance }\end{array}$

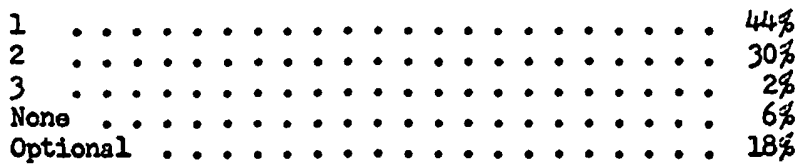

Intermediate Lovel (Second Year)

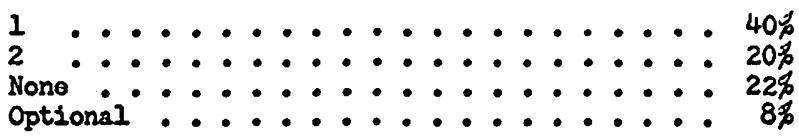

B. Positive Group

Flrst Year Lovel
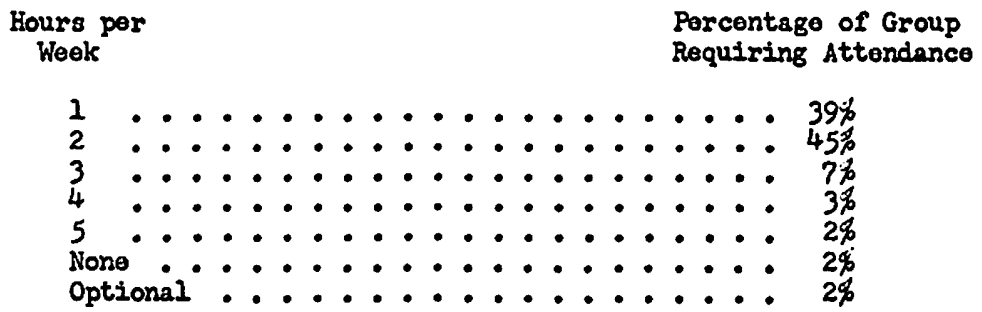

Intermediate Level (Second Year)

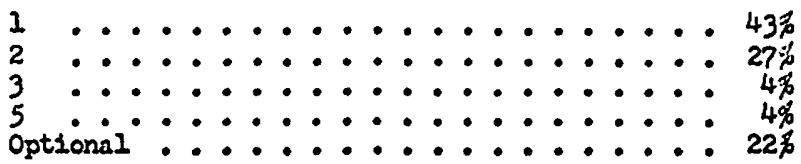


Membership in Professional Organizations

Negative Group (50)

1. AATE

2. AATG

3. AATI

4. AATSF

5. ACTFL

6. FIANC

7. CTA

8. MIA

9. MIASC

10. NAIID

68

208

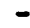

228

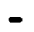

$18 \%$

$32 \%$

$14 \%$

$6 \%$
Positive Group (100)

$13 \%$

$22 \%$

$3 \%$

$22 \%$

$22 \%$

$16 \%$

458

$22 \%$

118

48

\section{Key:}

AATF - American Association of Teachers of French

AATG - American Association of Teachers of German

AATI - American Association of Teschers of Italian

AATSP - American Association of Teachers of Spanish and Portuguese

ACTFL - Americen Council on the Teaching of Foreign Isnguages

FLANC - Foreign Language Association of Northern California

CTA - Classroom Teachers Association

MIA - Modorn Ianguago Association

MLASC - Modern Language Association of Southern Californis

NALID - National Association of Language Laboratory Directors 